PIWULANG: Jurnal Pendidikan Agama Islam, Vol. 3 No. 2 Maret 2021, 173-185

P-ISSN : 2622-5638. E-ISSN : 2622-5654

Homepage: http://e-journal.staima-alhikam.ac.id/index.php/piwulang

\title{
HOME LEARNING SEBAGAI SOLUSI PEMBELAJARAN DI SEKOLAH DASAR ERA PANDEMI
}

\author{
Muh. Rodhi Zamzami \\ STAI “Ma'had Aly Al-Hikam Malang - INDONESIA \\ email: mrzamzami@gmail.com
}

\begin{abstract}
Education is a very important part of community life, without community education it is difficult to lead a more advanced and better life. The dilematization experienced by the world of education is very difficult, for one year the whole world has experienced a viral disaster that causes people to have to limit certain activities, including activities in education. Here I will discuss the impact of the pandemic on education, focusing on primary school education in Malang. The impact of the pandemic, education in primary schools has experienced tremendous obstacles so that the usual activities carried out are hampered and carried out abnormally. Learning solutions with the home learning system are an option for the continuous running of the learning system. Various strategies and methods have been applied as a strategic step, in order to anticipate the distance and time between teachers and students in carrying out learning.
\end{abstract}

\section{ABSTRAK}

Pendidikan bagian dari kehidupan masyarakat yang sangat penting, tanpa pendidikan masyarakat sulit untuk menempuh kehidupan yang lebih maju dan lebih baik. Dilematisasi dialami oleh dunia pendidikan sangat menyulitkan, sudah satu tahun ini seluruh dunia mengalami bencana virus yang menyebabkan orang harus membatasi beberapa aktifitas tertentu, tidak terkecuali aktifitas dalam pendidikan. Di sini saya akan membicarakan dampak pandemic terhadap pendidikan, fokus pada pendidikan sekolah dasar di malang raya. Dampak dari pandemic, pendidikan di sekolah dasar mengalami hambatan yang luar biasa sehingga aktifitas yang biasa dilaksanakan terhambat dan dilaksanakan secara tidak normal. Solusi pembelajaran dengan sistem home learning menjadi sebuah pilihan demi berjalanya sistem pembelajaran secara menerus. Dengan berbagai strategi dan metode telah diterapkan sebagai langkah strategis, guna mensiasati jarak dan waktu antara guru dan murid dalam melaksanakan pembelajaran.

Kata Kunci: Home Learning, Pandemic, Strategi Pembelajaran.

- $\quad$ Muh. Rodhi Zamzami - 173 
PIWULANG: Jurnal Pendidikan Agama Islam, Vol. 3 No. 2 Maret 2021, 173-185

P-ISSN : 2622-5638. E-ISSN : 2622-5654

Homepage: http://e-journal.staima-alhikam.ac.id/index.php/piwulang

\section{A. PENDAHUluan}

Home learning merupakan salah satu model pembelajaran yang sudah mulai tidak asing di kalangan masyarakat. Home learning merupakan model pembelajaran yang menekankan pembelajaean mandiri di lingkungan keluarga. Pada masa pandemi seperti sekarang home learning sangat dibutuhkan. Melihat kondisi satu tahun terahir ini bisa dikatakan sangat memprihatikan, semua elemen tidak memandang umur, waktu, maupun usia terkena dampak dari pandemic covid 19 ini.

Dampak dari adanya covid ini pendidikan mulai dari tingkat dasar sampai perguruan tinggi harus dialihkan ke sistem daring. Banyak kendala dialami dunia pendidikan khususnya. Mulai dari segi pembelajaran, pembiayaan dan menyikapi pandemi ini secara bijak dengan tetap menjaga proses pendidikan secara langsung. Banyak keluhan yang diutarakan oleh siswa, bisa dikatakan siswa belum siap menghadapi sistem pembelajaran daring. Sistem pendidikan yang mengharuskan untuk dilaksanakan secara daring, menuntut siswa dan orang tua untuk mengadakan alat komunikasi berupa smartphone guna menunjang pemberlajaran.

Belum lagi perekonomian keluarga yang dominan berada pada tingkat rendah, sehingga sangat sulit untuk memiliki perangkat komunikasi yang mendukung untuk pembelajaraan daring. Ada sebagian dari orang tua menyatakan kepada salah satu Guru di MI "bagaimana mungkin orang tua bisa mendampingi anaknya untuk melakukan pembelajaran daring sedangkan mereka gagap teknologi dan hanya memiliki pendapatan yang hanya cukup untuk makan sehari-hari?"1.

Bagaimanapun situasi yang sedang terjadi, pendidikan tidak boleh berhenti, karena pendidikan adalah hal yang dianggap penting untuk tetap terlaksana dalam kondisi bagaimanapun. Home learning sebagai salah satu sistem pemebelajaran sudah diwacanakan sebelum adanya kondisi pandemi. Suatu sistem yang dirasa baru tentu ada pro dan kontra di setiap kalangan. Namun dalam kondisi sebagaimana yang kita rasakan dari dampak pandemi saat ini home learnig adala sebuah solusi yang harus direalisasikan, terlepas ada yang pro dan kontra.

\section{B. METODE}

Penelitian ini adalah penelitian kualitatif, dengan pendekatan fenomenologi. Fokus utama studi fenomenologi ini adalah makna berbagai pengalaman, peristiwa, dan status yang dimiliki oleh partisipan. Studi ini juga berupaya untuk mengeksplorasi pengalaman personal dan

\footnotetext{
${ }^{1}$ Wawancara dengan Faiqotul Ahmaliya Guru MI pada 15 Februari 2021 Jam 12.30 Wib
} 
PIWULANG: Jurnal Pendidikan Agama Islam, Vol. 3 No. 2 Maret 2021, 173-185

P-ISSN : 2622-5638. E-ISSN : 2622-5654

Homepage: http://e-journal.staima-alhikam.ac.id/index.php/piwulang

memfokuskan pada persepsi atau pendapat individu tentang pengalaman pada objek atau peristiwa. Dalam studi fenomenologi ini peneliti mengambil beberapa data dari penglaman guru-guru sekolah dasar untuk menjelaskan fenomena secara langsung dari beberapa sumber yang terjadi di lembaga pendidikan sekolah dasar di sekitar Malang raya.

Fenomenologi adalah pendekatan yang dimulai oleh Edmund Husserl dan dikembangkan oleh Martin Heidegger untuk memahami atau mempelajari pengalaman hidup manusia. Pendekatan ini berevolusi sebuah metode penelitian kualitatif yang matang dan dewasa selama beberapa dekade pada abad ke dua puluh. Fokus umum penelitian ini untuk memeriksa/meneliti esensi atau struktur pengalaman ke dalam kesadaran manusia. ${ }^{2}$

Pengumpulan data dari penelitian ini diperoleh dengan wawanacara tertulis, termasuk dengan menggunakan wawancara mendalam atau indepth interview. Wawancara mendalam ini digunakan untuk memperoleh mendetail tentang fenomena atau pendidikan yang diteliti. Data yang diperolah dari in-depth interview ini selanjutnya dianalisis dengan menggunakan Interpretative Phenomenological Analysis (IPA).

\section{PEMBAHASAN}

\section{Pembelajaran Mandiri Era Digital}

Dinamika pendidikan terus berkembang, kita ketahui saat ini kita sudah memasuki era 4.0 atau bisa disebut dengan istilah four point o, dan sebentar lagi sudah masuk ke era 5.0 atau five point o. Hal ini bisa kita anggap sebagai berita yang baik juga bisa menjadi berita yang menyulitkan. Saya mengatakan demikian karena zaman semakin maju dan berkembang, namun kita perlu mengingat sudah sampai mana kesiapan kita untuk bisa mengikuti perkembangan zaman yang sangat cepat ini. Jika ternyata kesiapan kita masih belum maksimal kita pasti akan banyak ketinggalan dengan Negara-negara yang sudah memiliki kesiapan lebih dulu.

Hal diatas tidak bisa kita lepaskan dari persiapan yang kita lakukan pada generasi penerus kita, pendidikan yang kita laksanakan apakah mampu untuk menjawab perkembangan zaman yang pesat ini. sehingga kita mampu menghantarkan siswa kita pada zamanya dengan baik.

Pendidikan jarak jauh telah berkembang sejak 1883. Seiring dengan perkembangan ilmu pengetahuan dan teknologi. Pendidikan

\footnotetext{
2 Tuffour, Isaac. A Critical Overview of Interpretative Phenomenological Analysis: A Contemporary Qualitative Research Approach. Journal of Healthcare Communications. 2017. Vol. 2 No. 4, Juli 2017. DOI: $10.4172 / 2472-1654.100093$
}

- $\quad$ Muh. Rodhi Zamzami - 175 
PIWULANG: Jurnal Pendidikan Agama Islam, Vol. 3 No. 2 Maret 2021, 173-185

P-ISSN : 2622-5638. E-ISSN : 2622-5654

Homepage: http://e-journal.staima-alhikam.ac.id/index.php/piwulang

jarak jauh dapat di klasifikasikan melalui beberapa fase generasi sampai saat ini dengan generasi kelima. Posisi e-learning dalam pendidikan jarak jauh meerupakan suatu bentuk konsekuensi logis, saat ini kita dalam kondisi yang mengharuskan e-learning, karena keterpisahan jarak dan waktu antara peserta belajar dan penyelenggara pembelajaran, maka mutlak diperlukan pembelajaran berbasis teknologi informasi dan komunikasi. ${ }^{3}$

Pelaksanaan pendidikan jarak jauh juga diatur dalam undangundang RI No. 12 Tahun 2012 tentang Pendidikan Tinggi Pasal 31 ayat 1 dinyatakan bahwa pendidikan jarak jauh merupakan proses belajar mengajar yang dilakukan secara jarak jauh melalui penggunaan media komunikasi.

Peraturan Menteri Pendidikan dan Kebudayaan RI No. 24 tahun 2012 tentang penyelenggaraan pendidikan jarak jauh (PJJ) pada pendidikan tinggi pasal 2 ayat 1 dan 2 mencakup: berfungsi sebagai bentuk pendidikan peserta didik yang tidak dapat mengikuti pendidikan tatap muka tanpa mengurangi kualitas pendidikan, kemudian pendidikan jarak jauh bertujuan untuk meningkatkan perluasan dan pemerataan akses terhadap pendidikan yang bermutu dan relevan dengan kebutuhan.

Menteri Riset Teknologi dan Pendidikan Tinggi (Menristekdikti), Mohamad Nasir, Jakarta, Rabu, 6 Februari 2019 "lembaga sudah melakukan PJJ tahun 2019 meningkat dari lima perguruan tinggi menjadi 15 kampus. Kemarin lima tahun 2018. Sekarang tambah tujuh dan tiga lagi masuk," Menristekdikti mengatakan pendidikan tinggi di Indonesia harus melakukan perubahan dengan melaksanakan Pendidikan Jarak Jauh (PJJ) yang bertujuan untuk mengantisipasi perkembangan dunia yang begitu cepat.

Mobile learning diharapkan menjadi solusi dan kemudahan pada siapa saja untuk mengakses informasi dan materi pembelajaran dari mana saja dan kapan saja tanpa terbatas ruang dan waktu. Mobile Learning merupakan pembelajaran dengan bantuan teknologi seluler nirkabel (smartphone). Mobile learning (m-learning) adalah pembelajaran yang memanfaatkan teknologi dan perangkat mobile. Dalam hal ini, perangkat tersebut dapat berupa PDA, telepon seluler, laptop, tablet PC, dan sebagainya.Dengan smartphone peserta didik

${ }^{3}$ Dewi Salma Prawiradilaga, Mozaik Teknologi Pendidikan E-Learning, Jakarta: Kencana, 2013, ISBN. 978-692-7985-13-1

- Muh. Rodhi Zamzami - 176 
PIWULANG: Jurnal Pendidikan Agama Islam, Vol. 3 No. 2 Maret 2021, 173-185

P-ISSN : 2622-5638. E-ISSN : 2622-5654

Homepage: http://e-journal.staima-alhikam.ac.id/index.php/piwulang

dapat mengakses konten pembelajaran yang sudah disediakan oleh pendidik, di mana saja dan kapan saja. ${ }^{4}$

\section{Strategi Pembelajaran Era Pandemi}

Situasi pandemi saat ini dirasakan semua elemen, tidak terkecuali dalam lembaga pendidikan, tentu membuat resah dan bingun para walimurid. Sehingga support dan motivasi pada orang tua diperlukan dari lembaga pendidikan sendiri. Perlu ada upaya untuk meyakinkan merkea bahwa; menghadapi kesulitan di masa pandemi ini tidak sendirian. Pembelajaran siswa yang tidak boleh terhenti ketika dalam kondisi apapun, terpaksa harus tetap berjalan, semua lembaga pendidikan mulai dari kepala sekolah dan guru berusaha untuk mencari cara pembelajaran yang tetap efektif dalam keterbatasan jarak dan tempat.

Proses pembelajaran jarak jauh kini telah diterapkan di seluruh satuan pendidikan di seluruh Indonesia, kesiapan guru dan siswa dalam home learning ini bervariasi antara siap dan tidak siap. Sejumlah sekolah yang terbiasa menggunakan perangkat teknologi dalam pembelajaran tentu tidak akan menemukan masalah. Namun sebaliknya sekolahsekolah yang baru pertama kali menggunakannya tentu akan membutuhkan waktu dalam penyesuaian.

Home learning adalah sebuah konsep pendidikan dengan sistem berbasis rumah yang dikelola secara mandiri oleh orang tua. Sistem ini dapat menjadi sebuah alternatif bagi ayah bunda yang menginginkan pendidikan sesuai dengan kebutuhan putra putrinya. ${ }^{5}$ Pembelajaran online pada pelaksanaannya membutuhkan dukungan perangkatperangkat mobile seperti telepon pintar, tablet dan laptop yang dapat digunakan untuk mengakses informasi dimana saja dan kapan saja. ${ }^{6}$ Penggunaan teknologi mobile memiliki kontribusi besar di dunia pendidikan, termasuk di dalamnya adalah pencapaian tujuan pembelajaran jarak jauh. ${ }^{7}$ Berbagai media juga dapat digunakan untuk mendukung pelaksanaan pembelajaran secara online. Misalnya kelas-

\footnotetext{
${ }^{4}$ Taufiq Nur Azis, Strategi Pembelajaran Era Digital, Annual Conference On Islamic Education And Social Sains (Aciedss 2019)

${ }^{5}$ Natalia Ridwan, Ning Nathan, dan Yulianti Hendra, Home Learning: Belajar Seru Tanpa Batas. (Gramedia Pustaka Utama 2018). Hal. 14

${ }^{6}$ Gikas, J., \& Grant, M. M, Mobile computing devices in higher education: Student perspectives on learning with cellphones, smartphones \& social media. Internet and Higher Education. (2013). https://doi.org/10.1016/j.iheduc.2013.06.002

${ }^{7}$ Korucu, A. T., \& Alkan, A. Differences between m-learning (mobile learning) and elearning, basic terminology and usage of m-learning in education. Procedia - Social and Behavioral Sciences. 2011. https://doi.org/10.1016/j.sbspro.2011.04.029
}

- $\quad$ Muh. Rodhi Zamzami - 177 
PIWULANG: Jurnal Pendidikan Agama Islam, Vol. 3 No. 2 Maret 2021, 173-185

P-ISSN : 2622-5638. E-ISSN : 2622-5654

Homepage: http://e-journal.staima-alhikam.ac.id/index.php/piwulang

kelas virtual menggunakan layanan Google Classroom, Edmodo, dan Schoology, ${ }^{8}$ dan applikasi pesan instan seperti WhatsApp. Pembelajaran secara online bahkan dapat dilakukan melalui media social seperti Facebook dan Instagram. ${ }^{9}$

Beberapa tawaran solusi yang diberikan satuan pendidikan (sekolah/madrasah) sebagai sistem pembelajaran di era pandemi ada beberapa cara yang diterapkan di lembaga pendidikan oleh Guru yang dapat dikelompokkan sebagai berikut: 10

Pertama, membuat prinsip home leraning itu belajar yang memudahkan dan menyenangkan. Karena belajar bersama orangtua harusnya lebih menyenangkan. Bisa menjadi ajang momen untuk mendekatkan orangtua dan anak. Cara belajar yang menyenangkan akan lebih bisa diterima oleh anak-anak, dengan kondisi yang sangat menegangkan di era pandemi ini bisa sedikit terhibur jika bisa melaksanakan pembelajaran dengan cara yang menyenangkan.

Kedua, Menjadikan Home Learning sebagai ajang pembelajaran orang tua terhadap anak untuk membangun karakter anak. Dari sini bisa kita lihat bahwa orangtua memiliki peran terpenting dalam membentuk karakter anak-anaknya. Pendidikan orang tua kepada anak merupakan kewajiban orang tua terhadap anak.

Pendidikan karakter disini yang dimaksud adalah keteladanan dari orangtua. Keteladanan. Home learning akan mendekatkan hubungan yang positif untuk anak dan orangtua, karena setiap kegiatan anak selalu dilaksanakan dengan orang tua secara bersama-sama. Bisa dimulai dari mulai terjaga sampai terlelap kembali, kegiatannya bisa berupa, pembiasaan sholat 5 waktu, shalat sunnah, tilawah quran, murojaah, hafalan doa doa, pembiasaan bina diri, dan lain sebagainya. Lalu bagaimanakah jika orangtua tidak bisa menemani kiarena bekerja? Bisa dilakukan dengan anggota keluarga yang lain yang menemani dirumah, tentunya tetap dengan pengawasan orangtua.

Kedisplinan, kemandirian, tanggung jawab, ketaqwaan, keimanan sudah menjadi tugas mereka. Lalu untuk tetap mengingat materi pembelajaran mereka selama disekolah bagaimana? Anak bisa diberikan tugas untuk membaca cerita, lalu menceritakan kembali, atau bisa juga diberi soal 3 buah jika tentang matematika dan dikerjakan

\footnotetext{
${ }^{8}$ Enriquez, M. A. S. Students' Perceptions on the Effectiveness of the Use of Edmodo as a Supplementary Tool for Learning. DLSU Research Congress. (2014). https://doi.org/10.1017/CB09781107415324.004

${ }^{9}$ Firman, Sari Rahayu Rahman, Pembelajaran Online di Tengah Pandemi Covid-19, Indonesian Journal of Educational Science (IJES), Volume 02, No 02 Maret 2020 ${ }^{10}$ Wawancara dengan Alif Ristiawati (Guru) pada 15 Februari 2021
}

Muh. Rodhi Zamzami - 178 
PIWULANG: Jurnal Pendidikan Agama Islam, Vol. 3 No. 2 Maret 2021, 173-185

P-ISSN : 2622-5638. E-ISSN : 2622-5654

Homepage: http://e-journal.staima-alhikam.ac.id/index.php/piwulang

bersama dengan orangtua. Seandainya hal-hal tersebut dilakukan maka anak anak sudah belajar tentang keshalihan bermasyarakat.

Pandemi -19 memang banyak mengakibatkan dampak negatif pada berbagai elemen tetapi kita juga mendapatkan dampak positif, sebagaimana yang disampaikan salah satu Guru MI Wahid Hasyim "bagi orang tua yang biasanya tidak sempat mendampingi putra putri mereka belajar dan hanya mempercayakan putra putri mereka belajar di sekolah kini mereka menyempatkan diri untuk mendampingi putra putri mereka".11

Ketiga, menjadikan home learning sebagai pembelajaran berbasis proyek. Pembelajaran berbasis proyek ini bukan hal baru lagi. Kelebihannya anak bisa terstimulasi untuk bereksplorasi, menilai, menginterprestasi, dan mendapatkan informasi secara mandiri sebagai bentuk hasil dari belajar. Hal ini sejalan dengan konsep Learning by doing, dengan orangtua sebagai model belajar (Learning by modelling), dan guru memberikan pijakan (learning by scaffolding) dan syarat keberhasilan belajar (compliance). Beberapa praktik pembelajaran yang dilakukan oleh guru adalah sebagai berikut:

"seperti halnya yang kami alami di sekolah kami yaitu MI Wahid Hasyim 02 DAU, sebuah madrasah ibtida'iyah yang terletak di pedesaan. Karena sangat minimnya fasilitas dan juga pengetahuan penduduk tentang teknologi, bukan hanya itu jaringan pun sangat sulit. Hal ini sangat mempengaruhi kegiatan pembelajaran jarak jauh yang diterapkan saat ini.... Pada lembaga kami hanya dapat melakukan pembelajaran jarak jauh melalui fasilitas grup whatsapp orang tua yang ada pada setiap kelas. Melalui grup whatsapp, para guru memberikan tugas harian kepada siswa sesuai dengan jadwal pelajaran dan jam yang sudah ditentukan guru. Siswa mempelajari materi yang diberikan secara mandiri kemudian mengerjakan tugastugas dan melalui grup tersebut para siswa melaporkan hasil belajarnya pada hari yang sama. Hari berikutnya materi dan tugas akan berganti lagi. ${ }^{12}$

Menururut Natalia Ridwan Home learning saat ini menjadi solusi yang tepat bagi sekolah untuk mengembalikan kepercayaan kepada orangtua. Guru yang memberikan rambu-rambu pelajaran, pijakan tugas

11 Wawancara dengan Fika Nurlidia (Guru) pada tanggal 16 Februari 2021 jam 08.30 Wib.

12 Wawancara dengan Fika Nurlidia (Guru) pada tanggal 16 Februari 2021 jam 08.30 Wib.

- $\quad$ Muh. Rodhi Zamzami - 179 
PIWULANG: Jurnal Pendidikan Agama Islam, Vol. 3 No. 2 Maret 2021, 173-185

P-ISSN : 2622-5638. E-ISSN : 2622-5654

Homepage: http://e-journal.staima-alhikam.ac.id/index.php/piwulang

/ proyek sesuai dengan tema yang telah dan akan dipelajari sesuai dengan interval waktu yang terdapat dalam kalender akademik. Yakinkan bahwa orangtua dan anak mampu berkolaborasi untuk dapat menyelesaikan tugas sekolah tersebut. ${ }^{13}$

Namun dalam kondisi kesiapan orang tua untuk saat ini masih belum bisa maksimal, Sekiranya hal-hal tersebut menjadi fokus aktivitas yang terlibat dalam home learning, kegiatan home learning ini tentu sangat berdampak pada penyampaian pembelajaran, salah satunya yaitu penyampaian materi dan pemberian tugas yang tidak maksimal. Karena jika guru memberikan materi sesuai porsi yang biasanya diberikan di sekolah tidak semua orang tua bisa mendampingi putra putrinya dengan maksimal, bahkan ada beberapa orang tua yang mengaku tidak tahu apa yang harus dilakukan ketika mendampingi putra putri mereka belajar. Dalam hal ini sangat jelas bahwa pembelajaran pada semester ini terhambat dan tidak dapat tersampaikan dengan baik.

Bagi orang tua yang bekerja tantangannya akan bertambah, karena selain mendampingi anaknya belajar mereka juga harus menyelesaikan pekerjaannya. Oleh sebab itu banyak siswa yang melaporkan hasil belajarnya pada malam hari karena menunggu orang tua mereka selesai bekerja. Maka dari itu guru tidak dapat membatasi waktu pelaporan hasil belajar, hanya dibatasi tidak sampai hari berikutnya saja. ${ }^{14}$

\section{ANALISIS}

Cerita awal pandemic dari beberapa guru sekolah dasar di Malang Raya bisa kita lihat bahwa berbagai komentar baik pro atau kontra bermunculan, baik di kalangan siswa, orang tua sampai guru-guru bahan pengamat mengenai belajar di rumah yang ditetapkan Pemerintah. Sebagian orang tua yang mendampingi atau mengajari anaknya belajar di rumah juga mengeluh dengan berbagai keluhan yang bermunculan di medsos. Mulai stress, pusing, bahkan protes karena merasa tugas yang diberikan para guru secara online terlalu banyak dan berat.

Memilih home learning sebagai cara mendidik, penting untuk dipertimbangkan. Saat ini banyak orang tua yang lebih memilih fokus bekerja, sehingga mengesampingkan buah hatinya di rumah yang juga membutuhkan perhatian. Banyak yang beranggapan bahwa pendidikan di

13 Natalia Ridwan, Home Learning, Belajar Seru Tanpa Batas, https://www.haibunda.com/parenting/20180315142919-61-16292/mengenal-homelearning-salah-satu-metode-mendidik-anak

${ }^{14}$ Wawancara dengan Fika Nurlidia (Guru) pada tanggal 16 Februari 2021 jam 08.30 Wib.

Muh. Rodhi Zamzami - 180 
PIWULANG: Jurnal Pendidikan Agama Islam, Vol. 3 No. 2 Maret 2021, 173-185

P-ISSN : 2622-5638. E-ISSN : 2622-5654

Homepage: http://e-journal.staima-alhikam.ac.id/index.php/piwulang

sekolah reguler sudah cukup. Padahal tidak demikian, lebih dari itu, banyak ayah ibu yang tidak tahu persis perkembangan putranya di sekolah dan di rumah. 15

Tidak sedikit orang tua langsung protes bahkan minta beban tugas dikurangi. Dengan berbagai alasan serta fakta masing-masing. Mulai kebanyakan beban, anak stres, bahkan sampai sakit dan masuk rumah sakit. Kondisi ini terpaksa diberlakukan karena keadaan darurat serta mencegah bahaya yang lebih besar dari penyebaran covid-19. Pembelajaran daring menjadi pilihan bagi Guru dan satuan pendidikan:

"sesuai ketentuan Pemerintah, siswa harus tetap masuk dengan metode belajar daring atau memberikan tugas via online, yang artinya ini merupakan pembelajaran jarak jauh kepada para muridnya. Jika kondisi sudah normal, tentu pembelajaran di sekolah akan dipulihkan kembali". ${ }^{16}$

Dalam kondisi seperti ini, salah seorang wali murid mengaku saatnya kita sadar, proses belajar anak itu tak cukup hanya di sekolah. Orang tua juga harus berperan, sekaligus saatnya menghargai peran dan pengabdian para guru."Tugas guru mendidik anak di kelas dari pagi sampai siang hari bukan pekerjaan mudah. Menghadapi anak satu kelas dengan beragam perilakunya jelas butuh triks dan kesabaran ekstra. Tapi, itulah jati dirinya seorang guru," 17 katanya saat diminta komentarnya mengenai belajar secara online ini.

Pembelajaran secara daring diimplementasikan dengan beragam cara oleh pendidik di tengah menghindari penyebaran covid-19. Namun implementasi itu dinilai tidak maksimal dan menunjukkan masih ada ketidaksiapan di kalangan pendidik untuk beradaptasi dengan dunia digital. Sebagai mana yang diungkapkan salah satu guru MI KH. Romly Tamim Poncokusumo Mudiati Istiyani:

"ada beberapa siswa yang tidak memiliki HP untuk digunkan sebagai pembelajarannya ada pula orang tua yang tidak mengerti dengan tehnologi, namun himbauan dari pihak lembaga siswa di suruh untuk belajar bersama dengan tetangganya yang satu kelas ketika jam sekolah, agar tidak ketinggalan informasi dan tugas. ${ }^{18}$

15 Review: Home Learning: Belajar Seru Tanpa Batas (2018) https://wennykinanthi.wordpress.com/2018/11/25/review-home-learning-belajar-serutanpa-batas-2018/

16 Wawancara Firda Ayni (Guru MI) pada 17 Februari 2021 jam 10.00 Wib

17 Wawancara Firda Ayni (Guru MI) pada 17 Februari 2021 jam 10.00 Wib

${ }^{18}$ Wawancara Mudiati Istiyani (Guru MI) pada 18 Februari 2021 jam 12.10 Wib

- Muh. Rodhi Zamzami - 181 
PIWULANG: Jurnal Pendidikan Agama Islam, Vol. 3 No. 2 Maret 2021, 173-185

P-ISSN : 2622-5638. E-ISSN : 2622-5654

Homepage: http://e-journal.staima-alhikam.ac.id/index.php/piwulang

Guru dituntut untuk sekreatif mungkin memberikan tugas dan pembelajaran kepada siswa yang membuat mereka tidak bosan dirumah dan tidak merasa terbebani karena tugas yang menumpuk. Sampai saat ini alhamdulillah mereka merasa nyaman dan senang bahkan mereka rindu akan sekolah. Orang tua juga merasa bangga dengan putra putrinya karena dirumah mereka bisa membantu orang tuanya dan belajar dengan baik. Karena guru memberikan tugas pembiasaan piket dirumah dan sholat berjamaah bersama orang tua ataupun keluarga sebagai bentuk penilaian sikap spiritual dan sikap sosial siswa dirumah. ${ }^{19}$

Dalam keadaan seperti ini, peran orangtua sangat penting dalam membantu metode Pembelajaran home learning putra- putrinya. Keadaan ini juga memberi tantangan sendiri bagi para guru, murid tak hanya mengerjakan tugas akademis, melainkan juga melakukan kegiatan menyenangkan agar keinginan belajar para murid tetap tinggi.

Para guru di MI Miftahul Huda menyajikan materi pembelajaran dan membahasnya di grup WhatsApp yang beranggotakan para orang tua siswa. Mata pelajaran dan tugas-tugas dibahas grup itu. Dan para orang tua memantau secara langsung bahan pelajaran serta sejauh mana kompetensi dan kemampuan anaknya. Komunikasi dua arah juga terjalin ketika ada ketidakpahaman akan tugas yang diberikan. Siswa-siswi dibekali buku paket dan masing-masing dibawa ke rumah. Jadi memudahkan setiap materi yang kami arahkan lewat grup begitupun pemberian tugas-tugas. Dan jika ada yang ingin ditanyakan juga lewat grup WhatsApp.

Bukan hanya memantau materi pelajaran pokok, kebiasaankebiasaan lain yang selama ini diajarkan di sekolah pun diterapkan di rumah. Di antaranya hafalan surat-surat pendek, pelaksanaan salat Dhuha, pelaksanaan sholat 5 waktu dan piket bersih- bersih lingkungan sekitar. Orang tua senantiasa melaporkan aktivitas - aktivitas itu dalam bentuk rekaman video yang dikirim melalui Whatsapp. Bahkan Penilaian Tengah Semester (PTS) dilakukan melalui sistem online atau daring.

Kendala yang terjadi dalam Pembelajaran home learnijng adalah ketidakpahaman siswa dan orangtua terhadap tugas yang diberikan dan keterlambatan siswa dalam mengumpulkan tugas. Namun ada juga manfaat yang diperoleh selama home learning diantaranya adalah terbangunnya komunikasi yang lebih intens antara guru dengan orang tua siswa. Karena proses belajar mengajar secara daring butuh peran serta orang tua siswa. Pada hari biasa atau sebelum corona mewabah, guru lebih banyak berinteraksi dengan siswa - siswi.Dan ketika KBM berubah dengan model

${ }^{19}$ Disarikan dari hasil Wawancara Mudiati Istiyani (Guru MI) pada 18 Februari 2021 jam 12.10 Wib

Muh. Rodhi Zamzami - 182 
PIWULANG: Jurnal Pendidikan Agama Islam, Vol. 3 No. 2 Maret 2021, 173-185

P-ISSN : 2622-5638. E-ISSN : 2622-5654

Homepage: http://e-journal.staima-alhikam.ac.id/index.php/piwulang

daring, guru dan orang tua kompak untuk bersama melakukan kontrol atau pemantauan terhadap putra putrinya.Selain itu, orangtua bisa mengetahui kemampuan anaknya masing-masing. ${ }^{20}$

Kendala juga muncul ketika ada penjelasan yang kurang bisa dipahami oleh siswa, guru hanya mengirimkan tugas tanpa memberi penjabaran. Belum lagi kalau guru masih belum begitu familiar menggunakan smatrphone sehingga menjadi permasalahan tersendiri. Apalagi kalau permasalahan teknologi ini terjadi pada orang tua siswa sehingga untuk melakukan pelaporan tugas anak yang notabenya harus menggunakan smartphone, sehingga menjadi kendala tersendiri. Tidak sedikit dari walimurid yang hanya bisa mengoprasikan WA grup dan tidak tahu Google Classroom serta aplikasi lain. Belum lagi ada beberapa siswa kelas II yang tidak memiliki WA, Ada juga yang mengeluh karena paket data cepat habis, anak jadi lebih sering main game dan lain sebagainya. Namun sisi positifnya sebagian besar dari orangtua lebih memperhatikan pembelajaran putra-putrinya, yang biasanya tidak pernah mendampingi putra-putri mereka. ${ }^{21}$

Kami juga melakukan pembelajaran menggunakan metode ELearning yaitu pembelajaran memanfaatkan teknologi informasi dan komunikasi. Sistem pembelajaran dilaksanakan melalui perangkat komputer (PC) atau laptop atau smartphoneyang terhubung dengan koneksi jaringan internet, biasanya kami melakukan pembelajaran bersama diwaktu yang sama sekitar jam 09.00-10.00 menggunakan grup di media sosial seperti Whatsapp (WA), telegram, aplikasi Zoom ataupun media sosial lainnya sebagai sarana pembelajaran sehingga dapat memastikan siswa belajar diwaktu bersamaan meskipun ditempat yang berbeda. Kamijuga memberikan tugas terukur namun tetap memastikan bahwa tiap hari pembelajaran peserta didik terlaksana tahap demi tahap dari tugas tersebut. Namun masih ada kendala bagi siswa yang tidak memiliki akses internet.

\section{E. KESIMPULAN}

Home learning sebagai solusi dalam pembelajaran ini sangat memberikan kesan pada guru, siswa, dan juga wali murid. Dalam proses pembelajaran home learning ini menuntut suatu kerjasama yang baik antara guru, murid, dan orang tua. Sehingga dengan upaya itu mampu untuk tetap menjaga pembelajaran.

${ }^{20}$ Disarikan dari Wawancara Nafiatul Mukhoiyaroh (Guru MI) pada 17 Februari 2021 jam 10.15 Wib

${ }^{21}$ Disarikan dari Wawancara Nafilatul Maulida (Guru MI) pada 15 Februari 2021 jam 11.15 Wib

- Muh. Rodhi Zamzami - 183 
PIWULANG: Jurnal Pendidikan Agama Islam, Vol. 3 No. 2 Maret 2021, 173-185

P-ISSN : 2622-5638. E-ISSN : 2622-5654

Homepage: http://e-journal.staima-alhikam.ac.id/index.php/piwulang

Sekiranya dari hal yang dapat kita ambil sisi positif dari dampak pandemic ini adalah saling keterkaitan hubungan yang semakin kuat antara, orang tua dan siswa dalam bekerja sama untuk menjaga kondisi belajar siswa. Hal ini menjadi sebuah kesan positif dan mampu untuk menjadi sebuah refleksi atas jasa para guru dalam mendidik anak-anak yang sebelumnya mayoritas orang tua hanya memasrahkan pendidikan formal pada guru, hari ini para orang tua ikut merasakan bagaimana mendidik anak dalam dunia pendidikan formal.

Untuk home learning yang sudah berusaha untuk diimplementasikan dapa masa pendemi ini sedikit banya sudah menjawab permasalahan yang terjadi, namun penerapan dilapangan sudah tentu pasti dengan berbagai indikator tidak sesuai dengan teori secara utuh, karena sebebnarnya pembelajaran itu fleksibel sesuai dengan kondisi yang terjadi, sehingga setiap penerapan pembelajaran harus disesuaikan ukuranya dengan kondisi siswa, guru, dan juga sarana yang ada.

\section{DAFTAR PUSTAKA}

Dewi Salma Prawiradilaga, Mozaik Teknologi Pendidikan E-Learning, Jakarta: Kencana, 2013, ISBN. 978-692-7985-13-1

Taufiq Nur Azis, Strategi Pembelajaran Era Digital, Annual Conference On Islamic Education And Social Sains (Aciedss 2019)

Natalia Ridwan, Ning Nathan, dan Yulianti Hendra, Home Learning: Belajar Seru Tanpa Batas. (Gramedia Pustaka Utama 2018).

Gikas, J., \& Grant, M. M. (2013). Mobile computing devices in higher education: Student perspectives on learning with cellphones, smartphones \& social media. Internet and Higher Education. https://doi.org/10.1016/j.iheduc.2013.06.002

Korucu, A. T., \& Alkan, A. (2011). Differences between m-learning (mobile learning) and elearning, basic terminology and usage of m-learning in education. Procedia - Social and Behavioral Sciences. https://doi.org/10.1016/j.sbspro.2011.04.029

Enriquez, M. A. S. (2014). Students ' Perceptions on the Effectiveness of the Use of Edmodo as a Supplementary Tool for Learning. DLSU Research Congress. https://doi.org/10.1017/CB09781107415324.004

Firman, Sari Rahayu Rahman, Pembelajaran Online di Tengah Pandemi Covid19, Indonesian Journal of Educational Science (IJES), Volume 02, No 02 Maret 2020 
PIWULANG: Jurnal Pendidikan Agama Islam, Vol. 3 No. 2 Maret 2021, 173-185

P-ISSN : 2622-5638. E-ISSN : 2622-5654

Homepage: http://e-journal.staima-alhikam.ac.id/index.php/piwulang

Natalia Ridwan, Home Learning, Belajar Seru Tanpa Batas, https://www.haibunda.com/parenting/20180315142919-61-

16292/mengenal-home-learning-salah-satu-metode-mendidik-anak

Review: Home Learning: Belajar Seru Tanpa Batas (2018) https://wennykinanthi.wordpress.com/2018/11/25/review-homelearning-belajar-seru-tanpa-batas-2018/

Tuffour, Isaac. 2017. A Critical Overview of Interpretative Phenomenological Analysis: A Contemporary Qualitative Research Approach. Journal of Healthcare Communications. Vol. 2 No. 4, Juli 2017. DOI: 10.4172/24721654.100093

Wawancara dengan Faiqotul Ahmaliya Guru MI pada 15 Februari 2021 Jam $12.30 \mathrm{Wib}$

Wawancara dengan Alif Ristiawati (Guru) pada 15 Februari 2021 jam 08.00 Wib

Wawancara dengan Fika Nurlidia (Guru) pada tanggal 16 Februari 2021 jam 08.30 Wib.

Wawancara dengan Fika Nurlidia (Guru) pada tanggal 16 Februari 2021 jam 08.30 Wib.

Wawancara Firda Ayni (Guru MI) pada 17 Februari 2021 jam 10.00 Wib

Wawancara Mudiati Istiyani (Guru MI) pada 18 Februari 2021 jam $12.10 \mathrm{Wib}$

Disarikan dari hasil Wawancara Mudiati Istiyani (Guru MI) pada 18 Februari 2021 jam $12.10 \mathrm{Wib}$

Disarikan dari Wawancara Nafiatul Mukhoiyaroh (Guru MI) pada 17 Februari 2021 jam $10.15 \mathrm{Wib}$

Disarikan dari Wawancara Nafilatul Maulida (Guru MI) pada 15 Februari 2021 jam 11.15 Wib

- Muh. Rodhi Zamzami - 185 